\title{
Using airborne laser altimetry to estimate Sabellaria alveolata (Polychaeta: Sabellariidae) reefs volume in tidal flat environments
}

\author{
Mauricio Almeida Noernberg ${ }^{a, b, ~}{ }^{*}$, Jérôme Fournier ${ }^{b}$, Stanislas Dubois $^{c}$ and Jacques Populus ${ }^{c}$
}

\author{
${ }^{a}$ Centro de Estudos do Mar, Universidade Federal do Paraná, P.O. Box 50002, CEP 83255-000 \\ Pontal do Sul, PR, Brazil \\ ${ }^{\mathrm{b}}$ CNRS, UMR 7208 BOREA, Muséum National d'Histoire Naturelle, 38 rue du Port Blanc, 35800 \\ Dinard, France \\ ' IFREMER, DYNECO Ecologie Benthique, Technopole Brest-Iroise, BP70, 29280 Plouzané, France \\ *: Corresponding author : Mauricio Almeida Noernberg, email address : $\underline{\text { m.noernberg@ufpr.br }}$
}

\begin{abstract}
:
This study has exploited aerial photographs and LiDAR digital elevation model to quantify intertidal complex landforms volume. A first volume estimation of the main sabellariid polychaete reef complex of the Bay of Mont-Saint-Michel - France is presented. The Sabellaria alveolata is an engineering species that heavily modifies its environment. This gregarious tube-building annelid forms dense and solid reefs of bioclastic coarse sand which can reach several $\mathrm{km}^{2}$. Since 1970 a very strong decline of reefs has been observed. The authorities have curbed fishing activities without any noticeable changes in reef health status. The S. alveolata reef volume is estimated to be $132048 \mathrm{~m}^{3}\left(96301 \mathrm{~m}^{3}\right.$ for Sainte-Anne reef and $35747 \mathrm{~m}^{3}$ for Champeaux reef). Further LiDAR data surveys will be needed to be able to understand and quantify the accretion/erosion processes in play in the reef dynamic. Because of the internal variability of topographic complexity of the reef, characterized by crevices, cracks, and holes rather than whole blocks, further studies are needed to calculate more accurately the volume of the reef.
\end{abstract}

Keywords: LiDAR; volume; reef-building polychaete; Sabellaria alveolata; tidal flats; Bay of MontSaint-Michel 


\section{Introduction}

The sabellariid polychaete Sabellaria alveolata (Linnaeus, 1767) is known to form large intertidal colonies on the Northwestern coasts of Europe (Dubois et al., 2002). This gregarious tube-building annelid forms dense and solid reefs of bioclastic coarse sand which can reach several $\mathrm{km}^{2}$ (Caline et al., 1992). As such, S. alveolata can be considered as the most important building organism in temperate coastal environments (Naylor and Viles, 2000). The tubes constructed are joined together with a biomineralised cement (Gruet et al., 1987; Fournier et al., 2010), forming 1.20 to $1.80 \mathrm{~m}$ thick honeycomb-like structures (Kirtley and Tanner, 1968, and see pictures in Dubois et al., 2003 and Dubois et al., 2005). For sedimentologists, the study of these bioconstructions is of a primary importance because although this polychaete does not produce carbonate (unlike serpulids) it can nevertheless concentrate carbonate-rich sediments in its biogenic constructions. $S$. alveolata is known to actively control the texture and the distribution of intertidal sediments because of their ability to trap and selectively concentrate particles of specific mineralogy and clast-size (Gruet and Bodeur, 1994). S. alveolata is an engineer species that heavily modify its environment by offering various spatial and trophic niches within reef structures for many invertebrate and vertebrate species to colonize and develop (Dubois et al., 2006). Moreover, by modifying local hydrodynamics reef structures create various patterns of sedimentary facies that also affect associated benthic assemblages of immediate surrounding sediments (Dubois et al., 2002). However, this patrimonial species is locally submitted to strong anthropogenic disturbances either directly through trampling and shell-fishing or indirectly through shellfish cultures that surrounded the largest part of the reef: not only S. alveolata reefs are exploited with destructive manual fishing methods for epibiotic species (e.g. oysters Crassostrea gigas and mussels Mytilus edulis) that colonized reef surface (Dubois et al., 2006), but the development of this suspension-feeding polychaete is also hampered by an increase in seston concentration due to bivalve feeding activity and shellfish aquaculture techniques (Dubois et al., 2009). Degraded zones are hence rapidly spreading over the reef area and even occurred as the main structural feature for large portions of the whole reef. Mussel culture installations (wooden poles) surrounding the reef have considerably modified the hydrodynamic patterns, by increasing the sedimentation of muddy sediments and by limiting the coarse bioclastic grained sediment supply necessary for bioconstruction (Bonnot-Courtois et al., 2002). After a very strong decline of the reefs between 1970 and 2000, authorities curbed fishing activities though without noticeable changes in reef health status at the present time.

Detailed surveys of $S$. alveolata reefs were achieved with remote sensing techniques mainly using satellite images (Marchand and Cazoulat, 2003), aerial photographs (Bonnot-Courtois et al., 2005), or acoustic survey techniques (side-scan sonar) (Tessier et al., 2006). These techniques enable to quickly map the surface and the contours of the reefs and provide for scientists and environmental managers accurate information on the spatial decline of the reefs. However, information related to reef volume are lacking and yet are of paramount importance in estimating crucial parameters such as eroded or newly growth structures. For example, three-dimensional metrics are increasingly used to understand and managed coral reef extension or regression all over the world (Jones et al., 2008). As for Sabellariid reefs, only two previous topographical studies were realized in the Bay of Mont-Saint-Michel in 1964 and 1980 by Mathieu (1967) and Le Rhun and Mathieu (1982) with a surveyor's level and a theodolite, respectively. Comparisons between these surveys had shown that an elevation of the tidal flat corresponding to the general rising of the zone was a result of the sedimentary deposits 
(Bonnot-Courtois et al., 2002). These changes in altitude exceeded one metre in some places, hence revealing drastic changes in the general 3D configuration of the whole reef structure. A new detailed survey of the reef, twenty five years after the last topographic survey is thus necessary to provide an accurate state of the reef volume that could very likely serve as a relevant tool to monitor reef degradation. In that perspective, tools designed to investigate reefs engineered by polychaetes has received considerable attention from environmental managers as they are a relevant biological model to demonstrate conservation problems and assess whether recovery programs are effective or not (Godet et al., 2008; Hendrick and Foster-Smith, 2006; Toupoint et al., 2008).

Overall, remote-sensing data combined with existing survey data in a geographical information system (GIS) have been used to study intertidal habitats and to model coastal habitats (e.g.; Curnutt et al., 2000; Shanmugan et al., 2003; Brown, 2004; Belluco et al., 2006; Sellars and Jolls, 2007). Topographic metrics such as elevation or ground slope can be extracted from digital elevation models (DEMs) (Sinton et al., 2000; Thompson et al., 2001). The lack of high-resolution DEMs has been a limiting factor for ecosystem investigations, notably in the intertidal zone, where elevation data has the potential to increase discrimination of intertidal species by providing surrogate data for position within the tidal cycle (Brown, 2004).

The LiDAR (Light Detection and Ranging) system, a recently developed technology, has provided a new source for generating DEMs with potential applications for sedimentological or ecological studies (Liu, 2008). Up until now, LiDAR system was used for benthic mapping (Lefsky et al., 2002; Populus et al., 2004), rugosity of coral reefs (Brock et al., 2004), salt marsh vegetation (Rosso et al., 2006), altimetric or bathymetric surveys (Irish and White, 1998; Krabill et al., 2000) and geomorphological studies (Lohani and Mason, 2001; Sallenger et al., 2003). Other applications were developed such as mapping the shoreline position (Robertson et al., 2004; Stockdon et al., 2002) or flood modelling floods (Cobby et al., 2001; Kenward et al., 2000). LiDAR is an active, airborne remote-sensing technology that uses laser beams, airborne global positioning system (GPS), and orientation data provided by an inertial measurement unit (IMU) to probe the atmosphere and generate elevation data with typical accuracies on the order of 0.15-0.20 m (Krabill et al., 1995; Sallenger et al., 2003). The advantages of LiDAR technology include rapid collection of dense topographic data over large areas, inexpensive topographic mapping over large areas when compared to traditional photogrammetry, multiple return capabilities, possibility to collect data at night and in shadowed areas. This method is non-invasive and non-detrimental to fragile areas (Irish and White, 1998; Krabill et al., 2000). A fine topographical knowledge provided by LiDAR data can improve the ability to resolve small-scale intertidal features. Such data can be very useful in the mapping of coastal habitats especially for the calculation of immersion time and the estimation of the available surface for organism settlement or the quantification of sedimentation phenomena.

In this study, LiDAR data were used for the first time to estimate the trapped volume of sediment from complex landforms, through the model of $S$. alveolata reefs in the Bay of Mont-Saint-Michel. This investigation aimed at providing a new approach to study Sabellariid bioconstructions and to monitor their erosion for future study.

\section{Material and methods}

\subsection{Study area}


The study was carried out on the main reef of Sabellaria alveolata in the Bay of MontSaint-Michel, locally named 'Sainte-Anne' reef, which is located in the central part of the bay (Fig. 1). The sedimentary environment of the bay is mainly controlled by tidal residual current patterns, typically characterised by an anticyclonic gyre off Cancale, a large cyclonic gyre around the Channel Islands and reduced drift of water masses to the north along the coast of Normandy. Gyres are partly disrupted under high wind velocity (Bonnot-Courtois et al., 2002). The largest reef complex formed by the colony of $S$. alveolata ( \pm 65 ha in 2002) is located at the edge of the two juxtaposed hydrosedimentary systems, i.e. where the roughness is strongest. The central part of the bay is characterised by high bioclastic content (25\% to 95\%) and shows a gradual decrease in mean grain size from the subtidal to the intertidal zone (Billeaud et al., 2007; BonnotCourtois et al., 2004). In this area, the tidal flat is mainly formed by very fine sand to coarse carbonate-rich sand, with superficial deposits of silt. Sedimentation rates are higher (3mm to $25 \mathrm{~mm} /$ year) in the intertidal zones and tend to decrease seawards (Bonnot-Courtois et al., 2002).

In addition to the central part of the bay, S. alveolata has colonised several large areas of the lower intertidal zone and some rocky substrates from the upper intertidal zone, close to the cliffs of Champeaux (Fig. 1). This species create a unique reef-like environment which regrouped a variety of structures: elevated platforms, more or less coalescent ball-shape structures, as well as ridges and veneers adhering to rocks. Each morphological structure is characteristic for different stages in the reef dynamics (Dubois et al., 2002, 2006). The evolution begins with the settlement of individual young recruits to first ball-shaped structures which then merge as they grow to construct tables and reef platforms. The lifespan of the species is around 4 to 5 years, but can reach 6 to 8 years, which under normal conditions allows the preservation of a number of colonies without a significant supply of young, lasting over a period of several years before all environmental conditions (e.g. temperature, wind, tide ranges) allow a massive recruitment (Ayata et al., 2009).

\subsection{Data set and accuracy}

LiDAR survey

A LiDAR survey was conducted at low tide on 23-24 September 2002 in the Mont SaintMichel Bay. The laser scanner was an ALTM 2025 with a frequency of $25000 \mathrm{~Hz}$, a scan angle of $40^{\circ}$ and a $30 \mathrm{~cm}$ diameter footprint. The operating altitude of 1000 meters yielded a swath of $725 \mathrm{~m}$ with about $20 \%$ overlap between two contiguous flight lines. The LiDAR data was processed in UTM 30 and later re-projected into the Lambert 93 projection, which both are based on the IAG-GRS80 ellipsoid. According to the operator Terra Imaging, vertical and horizontal accuracies were expected to be respectively better than 50 and $15 \mathrm{~cm}$ on smooth terrain and usually found in the literature (Baltsavias, 1999a; 1999b).

Accuracy of LiDAR point data 
The accuracy of the LiDAR data was controlled using four flat control areas located immediately behind the coastline on the periphery of the bay. One of these control areas was a soccer field surrounded by conspicuous objects such as railings and lampposts. These control areas were surveyed with a real-time kinematic (RTK) dGPS which generated a total of more than 4100 field measurements. The horizontal accuracy was first checked to remain within one meter using LiDAR hits on these conspicuous objects. Following this, the vertical check was carried out as follows. Only RTK measurements made on the flat and smooth part of the control areas (either bare soil or short grass) were selected. For each of them the closest LiDAR hit was searched within a radius of one meter and the two points were associated into a pair. Statistics made on the 4096 resultant pairs yielded a mean value of $0.004 \mathrm{~m}$ and a standard deviation of $0.06 \mathrm{~m}$.

\section{Accuracy of photo-interpretation polygons}

Photo-interpretation was based on standard 1/25000 colour aerial photographs from a 2000-2002 comprehensive survey carried out over the French coastal zone in low tide conditions by IGN (Institut Géographique National) referred to as the "orthophotographie littorale". The photographs were scanned at $0.5 \mathrm{~m}$ resolution and interpreted in a GIS to provide reef contours (Fig. 2). Total reef surface was estimated at $615084 \mathrm{~m}^{2}$.

The accuracy of the position of these polygons is affected by two factors. Firstly the absolute $(x, y)$ position of such ortho-photographs is usually given as 1 meter rms on land. On such vast tidal zones as those of Mont Saint-Michel, this value is likely to rise to about 2 meters due to the lack of conspicuous marks for aero-triangulation. The second factor affecting the positional accuracy of the polygons is the quality of the delineation by the photo-interpreter, which can be estimated at 2 pixels, hence a total quadratic error of 2.2 meters. The cartographic system of these photographs was "Lambert 2 étendu", the official French system using Clarke 1880 ellipsoid.

Vertical accuracy of LiDAR DEM

For the purpose of the analysis, the LiDAR point cloud was interpolated to a $2 \mathrm{~m}$ regular grid DEM (Digital Elevation Model). Interpolation was performed with ordinary kriging without anisotropy and a very small nugget effect. The total vertical error is to be taken as the quadratic sum of the standard deviation derived from ground control and the kriging error. As a first approximation this error is considered to amount to $0.1 \mathrm{~m} \mathrm{rms}$.

Errors when registrating LiDAR DEM and reef polygons

In order to compute reef volume, it was necessary to co-locate the two layers. As it was deemed best to leave reef polygons untouched, preference was given to re-projecting the LiDAR DEM from Lambert 93 to Lambert 2. In theory, co-location errors result from three terms, the respective locational errors of each layer (respectively $2.2 \mathrm{~m}$ and $1 \mathrm{~m}$ for reef polygons and DEM) plus the registration error. Registration error has two components, one associated with changing ellipsoids, which we can neglect and the other associated with grid resampling. The latter can be estimated at one pixel, i.e. 2 meters. The quadratic sum of these three terms results is an overall horizontal co- 
location uncertainty of 3.1 meters. The volume computation affected by a horizontal uncertainty of $3.1 \mathrm{~m} \mathrm{rms}$ and a vertical uncertainty of $0.1 \mathrm{~m} \mathrm{rms}$.

\subsection{Analysis procedure}

Some particular Sabellaria alveolata reef features must be considered for the analysis and volume estimate: 1 ) the complexity in topography involving the $S$. alveolata reefs and surrounding dunes did not allow for a detailed identification of the reefs using only the DEM derived from LiDAR (DEM lidar); 2) the reefs located in a sloped area, with a steepness gradient more than 3\% increase the difficulty in defining an elevation base for calculating the reef volume, which leads to an overestimation of volume and 3) the volume estimation is done over the reef portion above the sediment and did not take into account the buried part of the reef (i.e. underneath the sediment surface) for which no data are available. Given that the reefs are integrated with the local topography the elevation values within the reef areas were eliminated and a new DEM was generated $\left(D M_{\text {base }}\right)$. In this way, an elevation base accompanying the steepness gradient could be used as elevation base, thus improving the volume estimation accuracy. The photographs (Fig. 3a) and the DEM from LiDAR (Fig. 3b) were imported to $\mathrm{PCl}$ Geomatica v.10.0.3 (PCl Geometrics, Richmond Hill, Ontario, Canada) for analysis. S. alveolata reefs polygons from aerial photographs (Fig. 3c) were used to 'clip' the elevation data points to ensure that DEM values excluded were exactly those of the $S$. alveolata reefs. A triangulated irregular network function was used on the image without the reefs elevations in order to generate the new DEM (DEM base). The surface model applied was of a weight inversely proportional to the distance from the centre of the output pixel from the three vertices of the plane. After this the S. alveolata reef volume $\left(V_{\text {reef }}\right)$ was estimated using the $D M_{\text {base }}$ as elevation base under the bitmap mask as follows:

$\mathrm{V}_{\text {reef }}=\mathrm{V}_{\text {lidar }}-\mathrm{V}_{\text {base }}$

where: $V_{\text {lidar }}$ is the volume calculated from $D E M_{\text {lidar }}$, and $V_{\text {base }}$ is the volume calculated from $\mathrm{DEM}_{\text {base, }}$ both using zero as the elevation base.

\section{Results}

The interaction in topography between reefs structures and sand dunes generate errors in the $D E M_{\text {base }}$ calculation, when elevation values of $D E M_{\text {base }}$ are greater than $D E M_{\text {lidar }}$. This normally takes place when depressions inside the reefs occur and the sand boundaries present higher values of elevation (Huising and Gomes Pereira, 1998). This kind of error causes the reef volume to be underestimated. Examples of this can be observed in Figure 4 for different parts of the reef. It is possible to see the landward steepness gradient and the complex morphology involving the reefs and dunes. The correspondent area with $D M_{\text {base }}$ values greater than $D E M_{\text {lidar }}$ is $26.08 \%$ of the total area. This represents a significant underestimation of $S$. alveolata reefs volume. In order to eliminate this underestimation, a subtraction of the $D E M_{\text {base }}$ elevation values from the 
DEM $_{\text {lidar }}$ values was made. The result of this subtraction was a new layer where the negative values represent the error (DEM $\mathrm{error}_{\text {) }}$ (Fig. 3d). Following this, the actual reef

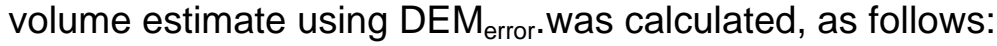

$\mathrm{V}_{\text {reef }}=\mathrm{V}_{\text {lidar }}-\mathrm{V}_{\text {base }}+\mathrm{V}_{\text {error }}$

The estimated reef volume was $94494 \mathrm{~m}^{3}$. We believe that this value is still underestimated because the volume over error area was considerate as zero, i.e. the reef was actually laying on the sediment. Several reef cores have already showed that the reef base originated at least $0.15 \mathrm{~m}$ underneath sediment surface and that this underground base fluctuated according to reef history. Accordingly, we added to the reef height the average value of the calculated reef base for each polygon ( $0.19 \mathrm{~m}$ for SainteAnne reef and $0.30 \mathrm{~m}$ for Champeaux reef), corresponding to the reef portion underneath the sediment surface. The reef volume is estimated to be $132048 \mathrm{~m}^{3}$ (96 $301 \mathrm{~m}^{3}$ for Sainte-Anne reef and $35747 \mathrm{~m}^{3}$ for Champeaux reef).

Additionally, the advantage of LiDAR (and associated DEMs) consists in the possibility to generate detailed topographic profiles. According to their relative position in the tidal flat and their topography, several morphological types of reefs can be distinguished. The Figure 5 presents five examples of North-South oriented profiles across the reef of Sainte-Anne. The visual interpretation of these profiles provides valuable information about local geomorphology and sedimentary movements. Transect 1 (Fig. 5, T1), located in the eastern part of the reef, revealed the difference in altitude between the sandy shoal 'La Grande Bosse' and the reef which is approximately four meters. This sandy shoal originated from the reef itself because of a so-called 'barrier effect' (Caline et al., 1992). The sandy shoal 'La Dune Plate' was created in the same way. Between these two sandy shoals and sheltered behind the reef, the transects 2 and 3 (Fig. 5, T2 and T3) show that the large rounded mud-flat is slightly higher than the reef. LiDAR transects provide accurate view and fine details of the reef topography (Fig. 5, T4 and T5). The reef consists in a succession of irregular depressions and bumps, sometimes by $0.50 \mathrm{~m}$ deep channels. The value of topographic LiDAR transects is based on their high accuracy. If more LiDAR data are acquired over time it will be possible to link the morphology of the reef with its dynamic and vitality. A dead reef would have a much smoother topographic signature. Thanks to available transects the extremely rough topography indicates that the reef is dynamic and continues its vertical accretion.

\section{Discussion}

LiDAR technique has received an increasingly interest in shallow coastal marine areas and have been used to map benthic habitat (Lefsky et al., 2002; Populus et al., 2004) or survey bathymetry (Krabill et al., 2000; Fikl et al., 2005; Wang \& Philpot, 2007). Very little use was made to estimates $3 \mathrm{D}$ volumes while this technique provides one of the most accurate and easy to deploy way to assess habitat volume. This study was especially designed to develop an ecological approach and demonstrate how useful this technique can be to study and monitor high patrimonial value benthic habitat such as Sabellaria alveolata reefs.

The volume calculated by LiDAR is an estimation of the whole volume of S. alveolata reefs. This volume (ca. $132048 \mathrm{~m}^{3}$ which cover an area of $615084 \mathrm{~m}^{2}$ ) which 
corresponds to the total reef volume, including what is underneath the sediment surface is probably underestimated, because it was not possible to consider the internal variability of the reef topographic complexity, characterized by crevices, cracks and holes, but it provides an estimate of consolidated sand that is trapped by the reef. In comparison, the estimated volume of all shell banks in the Bay of Mont-Saint-Michel was around $135000 \mathrm{~m}^{3}$ in 1993 (which cover an area of $511000 \mathrm{~m}^{2}$ ) (Bonnot-Courtois et al., 2002, Bonnot-Courtois et al., 2004), the volume represented by these reefs is therefore significant. In the reefs, calcium carbonate grains are more frequent (approximately $60 \%-80 \%$ ) than quartz and others insoluble grains (Caline et al., 1992; Gruet and Bodeur, 1994). The sand surrounding the reefs is richer in bioclasts and coarser grained that the tidal flat sand. These colonies actively control the texture and the distribution of intertidal sands because of their ability to trap and selectively concentrate particles of specific mineralogy (e.g. bioclasts) and grain-size. Trapping and binding of sand by marine organisms may play an important role in controlling clastic sediment distribution. As such, these bioconstructions provide a spectacular example of modern carbonaterich reefs living under temperate climate. However, without accurate topographical data, we cannot correctly estimate the trapped volume of sand and more precisely the trapped volume of calcium carbonate grains. With new further LiDAR data surveys, we will be able to understand and quantify the accretion/erosion processes in plays in the reef dynamic.

Volumetric change analysis of deposition or erosion along a coastline has been useful to understand dynamic processes driving benthic habitat in sediment supply (White and Wang, 2003; Brock et al., 2004; Shresthaa et al., 2005; Zhou and Xie, 2009). This approach has several ecological applications, especially for benthic habitat structured by engineer-species, often considered as high patrimonial and ecological value systems. Sabellaria reefs are probably the largest bioconstructions built by a polychaete on European coasts and as a 'reefs' they are listed under Annex I of the European Habitats Directive as a marine habitat to be protected by the designation of Special Areas of Conservation, meaning that maintain a favorable conservation status of such Sabellaria reef habitats. Decision-makers are hence looking for better decision-making for conserving, managing and protecting species and the systems they depend on. One of the main applications of LiDAR technique is that a discrete habitat like reef can be considered as 3D area, which is biologically more relevant (e.g. Hendrick and FosterSmith, 2006). Several investigations dealing with bioconstructed reefs have showed that while the total area covered by the reef can remained similar, the reef surface and the reef height can adversely be impacted, whether by natural burial (Sloan and Irlandi, 2008) anthropogenic pressures or bioeroding epibionts (Schonberg, 2002 ; Dubois et al., 2006). The application of changes in volume estimation for intertidal habitat is at an early stage, as found in Rosso et al. (2006) who used LiDAR to discern between Spartina species and marsh components, to quantify sediment dynamics associated with the Spartina invasion, and changes in Spartina structure and biomass. However, the fine topography obtained by LiDAR surveys enables a comprehensive visual/quantitative insight into the spatial patterns of morphological change that occur in intertidal environments and provides a relevant monitoring tool for decision makers to survey erosion of valuable coastal habitats.

\section{Conclusion}


This study has exploited aerial photographs and LiDAR digital elevation model to quantify intertidal complex landforms volume. A first volume estimation of the main worm-reef complex of the Bay of Mont-Saint-Michel is presented. The result also demonstrated that the LiDAR technique provide accurate information about the overall knowledge of one of the main reef-building species in the coastal environment. Data provided by LiDAR can be very useful for sedimentologists to calculate trapped sediment volume or for physicists to construct models of coastal sedimentary transfer.

Because of the internal variability of topographic complexity of the reef, characterized by crevices, cracks and holes rather than whole blocks, it seems necessary to carry out further studies to calculate more accurately the true volume of the reef. Several tools are available such as mathematical morphology (Soille, 2007) or fractal geometry (Burrough, 1981; Curl, 1986; Taud and Parrot, 2005) but the application methods must still be developed.

\section{Acknowledgements}

This project was supported by CNRS (Centre National de la Recherche Scientifique) and MNHN (Muséum National d'Histoire Naturelle) research grant. IFREMER (Institut Français de Recherche et pour l'Exploitation de la Mer) and the TOTAL Foundation provided us with support for aerial photographs and LiDAR data delivery and interpretation. We thank MSc A. Curd (MNHN) for English editing. We also thank the two anonymous external referees, whose comments improved the manuscript significantly.

\section{References}

Ayata, S.D., Ellien, C., Dumas, F., Dubois, S., Thiébaut, E. (2009). Modelling larval dispersal and settlement of the reef-building polychaete Sabellaria alveolata: Role of hydroclimatic processes on the sustainability of biogenic reefs. Continental Shelf Research, 29:1605-1623.

Baltsavias, E.P. (1999a). Airborne laser scanning: basic relations and formulas. ISPRS Journal of Photogrammetry and Remote Sensing, 54:199-214.

Baltsavias, E.P. (1999b). Airborne laser scanning: existing systems and firms and other resources. ISPRS Journal of Photogrammetry and Remote Sensing, 54:164- 198.

Belluco, E., Camuffo, M., Ferrari, S., Modenese, L., Silvestri, S., Marani, A., Marani, M. (2006). Mapping salt-marsh vegetation by multispectral and hyperspectral remote sensing. Remote Sensing of Environment, 105:54-67.

Billeaud, I., Tessier, B., Lesueur, P., Caline B. (2007). Preservation potential of highstand coastal sedimentary bodies in a macrotidal basin: Example from the Bay of Mont-Saint-Michel, NW, France. Sedimentary Geology, 202:754-775.

Bonnot-Courtois, C., Caline, B., L'Homer, A., Le Vot, M. (2002). The Bay of Mont-SaintMichel and the Rance Estuary, recent development and evolution of depositional environments. Mémoire 26, CNRS, EPHE, TotalFinaElf, Pau, 256 p.

Bonnot-Courtois, C., Fournier, J., Dréau, A. (2004). Recent morphodynamics of shell banks in the western part of Mont-Saint-Michel Bay (France). Géomorphologie: relief, processus, environment, 1:65-80. 
Bonnot-Courtois, C., Fournier, J., Rollet, C., Populus, J., Guillaumont, B., Loarer, R. (2005). Bio-morpho-sedimentary cartography of the tidal zones in the French Benthic Network context (complementary of coastal orthophotographs and Lidar data). Photointerprétation, 41:13-27.

Brock, J.C., Krabill, W.B., Sallenger, A.H. (2004). Barrier island morphodynamic classification based on lidar metrics for north Assateague Island, Maryland. Journal of Coastal Research, 20:498-509.

Brock, J.C., Wright, C.W., Clayton, T.D., Nayegandhi, A. (2004). LIDAR optical rugosity of coral reefs in Biscayne National Park, Florida. Coral Reefs, 23:48-59.

Brown, K. (2004). Increasing classification accuracy of coastal habitats using integrated airborne remote sensing. In: European Association of Remote Sensing Laboratories eProceedings, 3, SIG "Remote Sensing of the Coastal Zone", Editor Rainer Reuter, Ghent, Belgium, pp. 34-42.

Burrough, P.A. (1981). Fractal dimensions of landscapes and other environmental data. Nature, 294:240-242.

Caline, B., Gruet, Y., Legendre, C., Le Rhun, J., L'Homer, A., Mathieu, R., Zbinden, R. (1992). The Sabellariid reefs in the Bay of Mont Saint-Michel, France. Ecology, Geomorphology, Sedimentology and Geologic Implications. Edited and translated by David W. Kirtley, Florida Oceanographic Society, Contributions to Marine Science 1, Stuart, Florida, $156 \mathrm{p}$.

Cobby, D.M., Mason, D.C., Davenport, I. J. (2001). Image processing of airborne scanning laser altimetry data for improved river flood modeling. ISPRS Journal of Photogrammetry and Remote Sensing, 56:121-138.

Curl, R.L. (1986). Fractal dimensions and geometries of caves. Mathematical Geometry, 18:765-783.

Curnutt, J.L., Comiskey, J., Nott, M.P., Gross, L.J. (2000). Landscape-based spatially explicit species index models for Everglades restoration. Ecological Applications, 10:1849-1860.

Dubois, S., Barillé, L., Retière, C. (2003). Efficiency of particle retention and clearance rate in the polychaete Sabellaria alveolata L. Comptes-Rendus Biologies, 326:413-421.

Dubois, S., Barillé, L., Cognie, B. (2009). Feeding response of the polychaete Sabellaria alveolata (Sabellariidae) to changes in seston concentration. Journal of Experimental Marine Biology and Ecology, 376:94-101.

Dubois, S., Barillé, L., Cognie, B., Beninger, P.G. (2005). Particle capture and processing mechanisms in Sabellaria alveolata (Polychaeta: Sabellariidae). Marine Ecology Progress Series, 301:159-171.

Dubois, S., Commito, J.A., Olivier, F., Retière, C. (2006). Effects of epibionts on Sabellaria alveolata (L.) biogenic reefs and their associated fauna in the Bay of Mont Saint-Michel. Estuarine, Coastal and Shelf Science, 68:635-646.

Dubois, S., Retière, C., Olivier, F. (2002). Biodiversity associated with Sabellaria alveolata (Polychaeta: Sabellariidae) reefs: effects of human disturbances. Journal of Marine Biological Association of the United Kingdom, 82:817-826.

Finkl, C.W., Benedet, L., Andrews, J.L. (2005). Submarine Geomorphology of the Continental Shelf off Southeast Florida Based on Interpretation of Airborne Laser Bathymetry. Journal of Coastal Research, 21:1178-1190.

Fournier, J., Etienne, S., Le Cam, J.B. (2010). Inter- and intraspecific variability in the chemical composition of the mineral phase of cements from several tube-building polychaetes. Geobios, 43:191-200.

Godet, L., Toupoint, N., Olivier, F., Fournier, J., Retière, C. (2008). Considering the functional value of common marine species as a conservation stake. The case of the 
sandmason worm Lanice conchilega (Annelid polychaeta, Pallas 1766) beds. Ambio: A Journal of the Human Environment, 37:347-355.

Gruet, Y., Bodeur, Y. (1994). Sélection des grains de sable selon leur nature et leur forme par Sabellaria alveolata Linné (Polychète, Sabellariidé) lors de la reconstruction expérimentale de son tube. Mémoire du Muséum National d'Histoire Naturelle, 162:425432.

Gruet, Y., Vovelle, J., Grasset, M., 1987. Biomineral components of tube cement of Sabellaria alveolata (L.) (Annelida Polychaeta). Canadian Journal of Zoology, 65:837842.

Hendrick, V.J., Foster-Smith, R.L. (2006). Sabellaria spinulosa reef: a scoring system for evaluating 'reefiness' in the context of the Habitats Directive. Journal of Marine Biological Association of the United Kingdom, 86:665-677.

Huising, E. J., Gomes Pereira, L. M. (1998). Errors and accuracy estimates of laser data acquired by various laser scanning systems for topographic applications. ISPRS Journal of Photogrammetry and Remote Sensing, 53:245-261.

Irish, J.L., White, T.E. (1998). Coastal engineering applications of high-resolution LIDAR bathymetry. Coastal Engineering, 35:47-71.

Jones, A.M., Cantin, N.E., Berkelmans, R., Sinclair, B., Negri, A.P. (2008). A 3D modeling method to calculate the surface areas of coral branches. Coral Reefs, 27:521526.

Kenward, T., Lettenmaier, D., Wood, E., Fielding, E. (2000). Effects of digital elevation model accuracy on hydrologic predictions. Remote Sensing of Environment, 74:432444.

Kirtley, D.W. Tanner, W.F. (1968). Sabellariid worms: builders of a major reef type. Journal of Sedimentology and Petrography, 38:73-78.

Krabill, W.B., Thomas, R.H., Martin, C.B., Swift, R.N., Frederick, E.B. (1995). Accuracy of airborne laser altimetry over the Greenland ice sheet. International Journal of Remote Sensing, 16:1211-1222.

Krabill, W.B., Wright, C.W., Swift, R.N., Frederick, E.B., Manizade, S.S., Yungel, J.K., Martin, C.F., Sonntag, J.G., Duffy, M., Hulslander, W., Brock, J.C. (2000). Airborne lasermapping of Assateaque National Seashore beach. Photogrammetric Engineering and Remote Sensing, 66:65-71.

Lefsky, M.A., Cohen, W.B., Parker, G.G., Harding, D.J. (2002). Lidar remote sensing for ecosystem studies. BioScience, 52:19-30.

Le Rhun, J., Mathieu, R. (1982). Le banc des Hermelles de la baie du Mont-SaintMichel: les variations topographiques entre 1964 et 1980. Mémoires géologiques de I'Université de Dijon, 7:53-61.

Liu, X. (2008). Airborne LiDAR for DEM generation: some critical issues. Progress in Physical Geography, 32:31-49.

Lohani, B., Mason, D.C. (2001). Application of airborne scanning laser altimetry to the study of tidal channel geomorphology. ISPRS Journal of Photogrammetry and Remote Sensing, 56:100-120.

Marchand, Y., Cazoulat, R. (2003). Biological reef survey using spot satellite data classification by cellular automata method - bay of Mont Saint-Michel. Computers and Geosciences, 29:413-421.

Mathieu, R. (1967). Le banc des Hermelles de la baie du Mont-Saint-Michel. Bioherme à Annélides. Sédimentologie, structure et genèse. Bulletin de la Société Géologique de France, 9:68-78.

Naylor, L.A., Viles, H.A. (2000). A temperate reef builder: an evaluation of the growth, morphology and composition of Sabellaria alveolata (L.) colonies on carbonate platforms in South Wales. In Carbonate Platform Systems: components and interactions, Insalaco, 
E., Skelton, P.W. \& Palmer, T.J. (eds), Geological Society, London, Special Publications, 178:9-19.

Populus, J., Laurentin, A., Rollet, C., Vasquez, M., Guillaumont, B., Bonnot-Courtois, C., (2004.). Surveying coastal zone topography with airborne remote sensing for benthos mapping. In: European Association of Remote Sensing Laboratories eProceedings, 3, SIG "Remote Sensing of the Coastal Zone", Editor Rainer Reuter, Ghent, Belgium, pp. 105-117.

Robertson, W.V., Whitman, D., Zhang, K., Leatherman, S.P. (2004). Mapping shoreline position using airborne laser altimetry. Journal of Coastal Research, 20:884-892.

Rosso, P.H., Ustin, S.L., Hastings, A. (2006). Use of lidar to study changes associated with Spartina invasion in San Francisco Bay marshes. Remote Sensing of Environment, 100:295-306.

Sallenger, A.H., Krabill, W.B., Swift, R.N., Brock, J., List, J., Hansen, M., Holman, R.A., Manizade, S., Sontag, J., Meredith, A., Morgan, K., Yunkel, J.K., Frederick, E.B., Stockdon, H. (2003). Evaluation of topographic Lidar for quantifying beach changes. Journal of Coastal Research, 19:125-133.

Sellars, J.D., Jolls, C.L. (2007). Habitat modelling for Amaranthus pumilus: An applocation of light detection and ranging (LIDAR) data. Journal of Coastal Research, 23:1193-1202.

Shanmugan, S., Lucas, N., Phipps, P., Richards, A., Barnsley, M. (2003). Assessment of remote sensing techniques for habitat mapping in coastal dune ecosystem. Journal of Coastal Research, 19:64-75.

Schonberg, C.H.L., 2002. Pione lampa, a bioeroding sponge in a worm reef. Hydrobiologia 482, 49-68.

Shresthaa, R.L., Cartera, T.W.E., Sartoria, M., Luzuma, B.J., Slatton, K.C. (2005). Airborne Laser Swath Mapping: quantifying changes in sandy beaches over time scales of weeks to years. ISPRS Journal of Photogrammetry and Remote Sensing, 59:222-232. Sinton, D.S., Jones, J.A., Ohmann, J.L., Swanson, F.J. (2000). Windthrow disturbance, forest composition and structure in the Bull Run basin, Oregon. Ecology, 81:2539-2556.

Sloan, N.J.B., Irlandi, E.A., 2008. Burial tolerances of reef-building Sabellariid worms from the east coast of Florida. Estuarine Coastal and Shelf Science, 77:337-344.

Stockdon, H.F., Sallenger, A.H., List, J.H., Holman, R.A. (2002). Estimation of shoreline position and change using airborne topographic lidar data. Journal of Coastal Research, 18:502-513.

Soille P. (2007). From mathematical morphology to morphological terrain features. In Digital Terrain Modelling. Development and Applications in a Policy Support Environment. Peckham, R.J. \& Jordan, G (eds), Springer, Berlin, 45-66.

Taud, H., Parrot, J.F. (2005). Measurement of DEM roughness using the local fractal dimension. Géomorphologie: relief, processus, environment, 4:327-338.

Tessier, B., Billeaud I., Lesueur, P. (2006). The Bay of Mont-Saint-Michel northeastern littoral: an illustrative case of coastal sedimentary body evolution and stratigraphic organization in a transgressive/highstand context. Bulletin de la Société Géologique de France, 177:71-78.

Thompson, J.A., Bell, J.C., Butler, C.A. (2001). Digital elevation model resolution, effects on terrain attribute calculation and quantitative soil-landscape modeling. Geoderma, 100:67-89.

Toupoint, N., Godet, L., Fournier, J., Retière, C., Olivier, F. (2008). Does Manila clam cultivation affect habitats of the engineer species Lanice conchilega (pallas, 1766)? Marine Pollution Bulletin, 56:1429-1438.

Wang, C.K., Philpot, W.D. (2007). Using airborne bathymetric lidar to detect bottom type variation in shallow waters. Remote Sensing of Environment, 106:123-135 
White, S.A., Wang, Y. (2003). Utilizing DEMs derived from LIDAR data to analyze morphologic change in the North Carolina coastline. Remote Sensing of Environment, 85:39-47.

Zhou, G.Q., Xie, M. (2009). Coastal 3-D morphological change analysis using LiDAR series data: a case study of Assateague Island National seashore. Journal of Coastal Research, 25:435-447.

\section{Figures}

Figure 1. Location of the study area (Mont-Saint-Michel Bay, France).

Figure 2. Photo-interpretation of the Sainte-Anne reef and location of the topographical transects.

Figure 3. Example of analysis steps in a small part of Sainte-Anne reef. a) Standard $1 / 25000$ colour aerial photographs; b) DEM from LiDAR; c) polygons of $S$. alveolata from aerial photographs clipping the elevation data; d) subtraction of the $D E M_{\text {base }}$ elevation values from the $D E M_{\text {lidar }}$ values where negative values (red) are representing the error (DEM $\mathrm{error}$.

Figure 4. Topographical transects showing the digital elevation model derived from

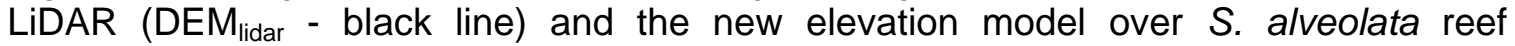
generated without reef elevation data $\left(D E M_{\text {base }}\right)$. The error $\left(D E M_{\text {error }}\right)$ is characterized where $D M_{\text {base }}$ values are greater than $D E M_{\text {lidar }}$. Shaded area represents the $S$. alveolata reef (polygon). (a) Champeaux reef; (b) e (c) Sainte-Anne reef.

Figure 5. North-South oriented topographical profiles from LiDAR across the intertidal zone which includes the reef of Sainte-Anne located in the central part of the Bay of Mont-Saint-Michel. Profiles allow to observe the internal organization of the reef which is a series of mounds and depressions. The barrier effect of the reef is also very visible. The reef allows an active sedimentation protecting the foreshore against swells. For this reason, highly developed sandy banks are visible inside or behind the reef. 


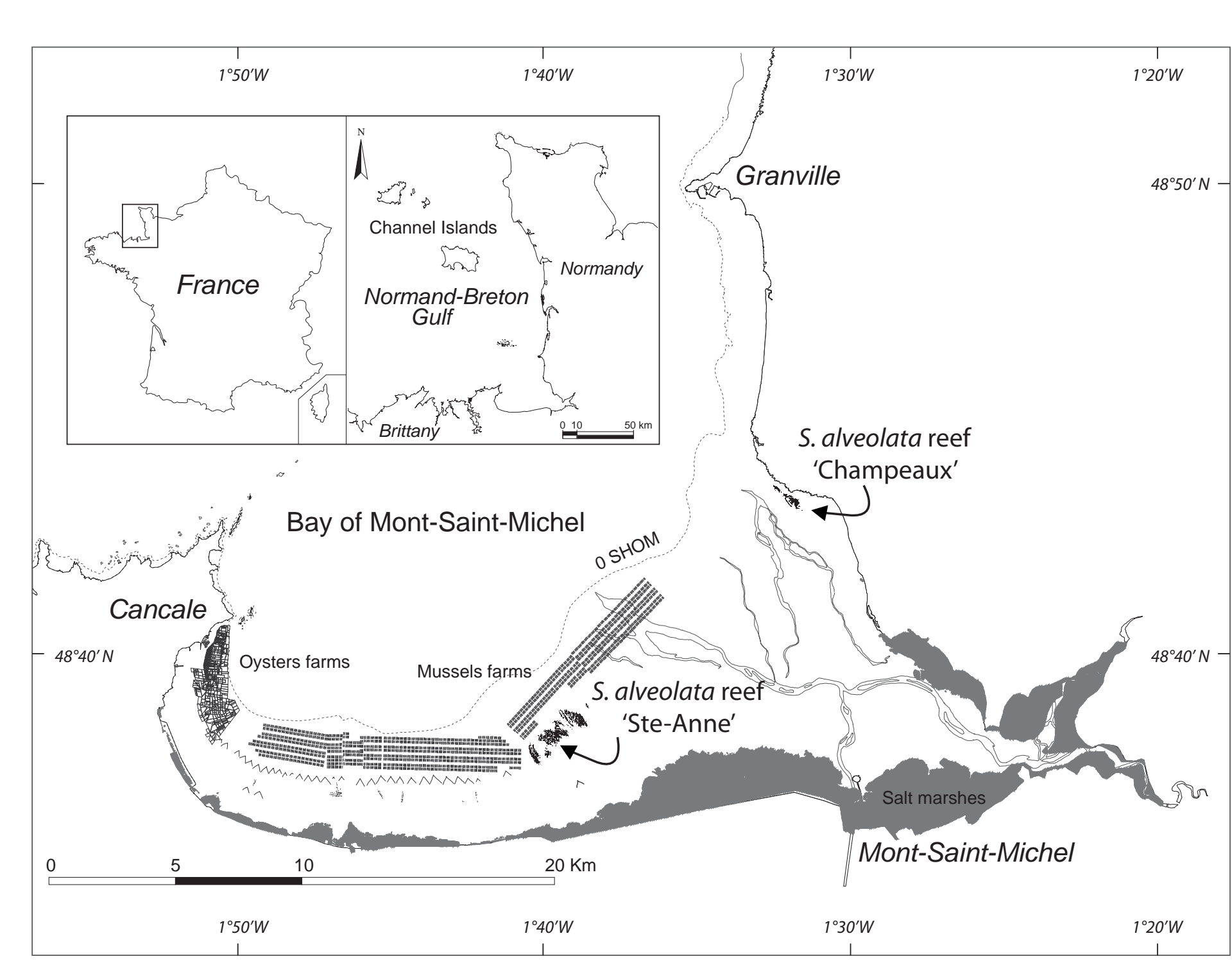




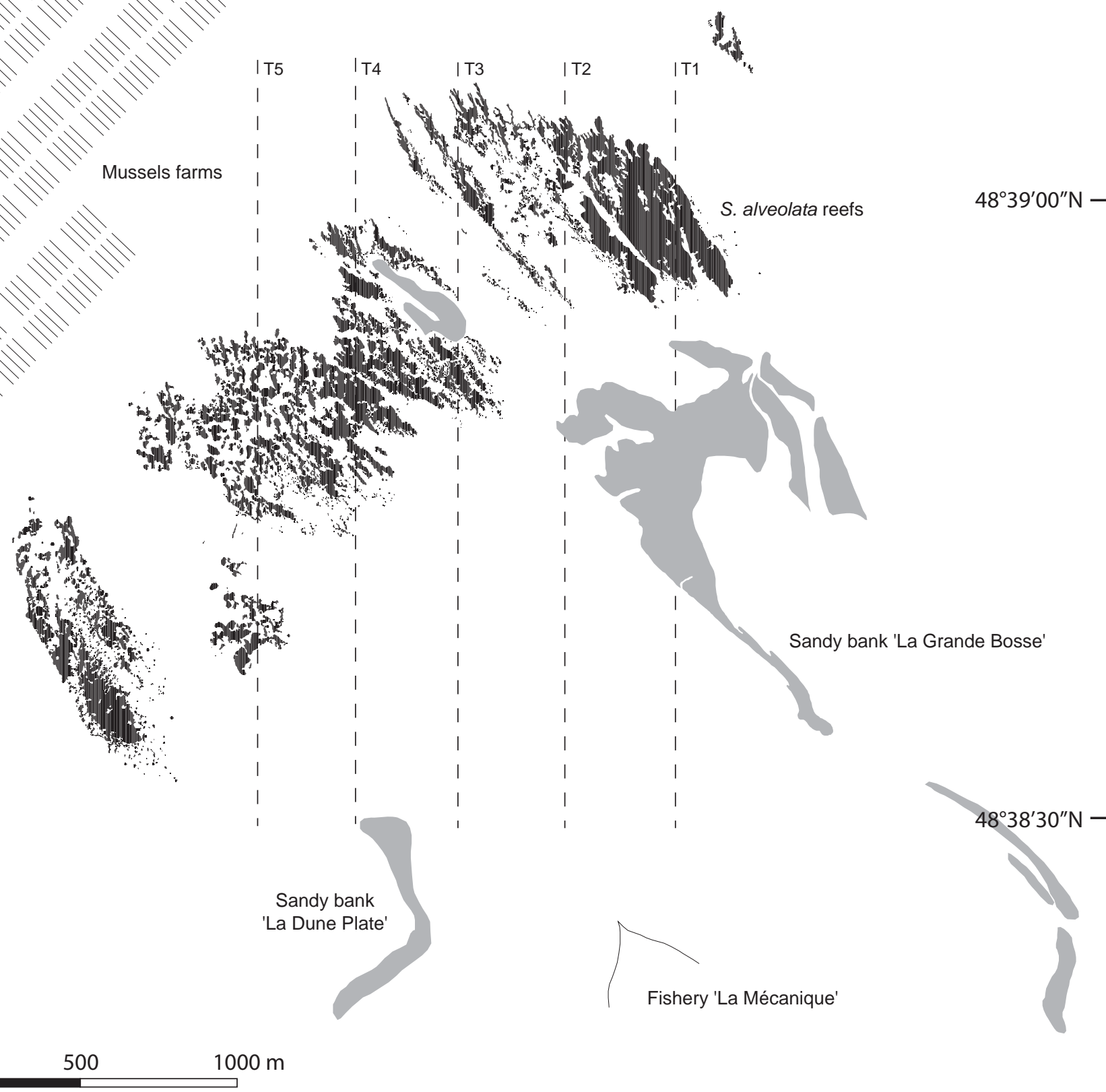





\section{North}
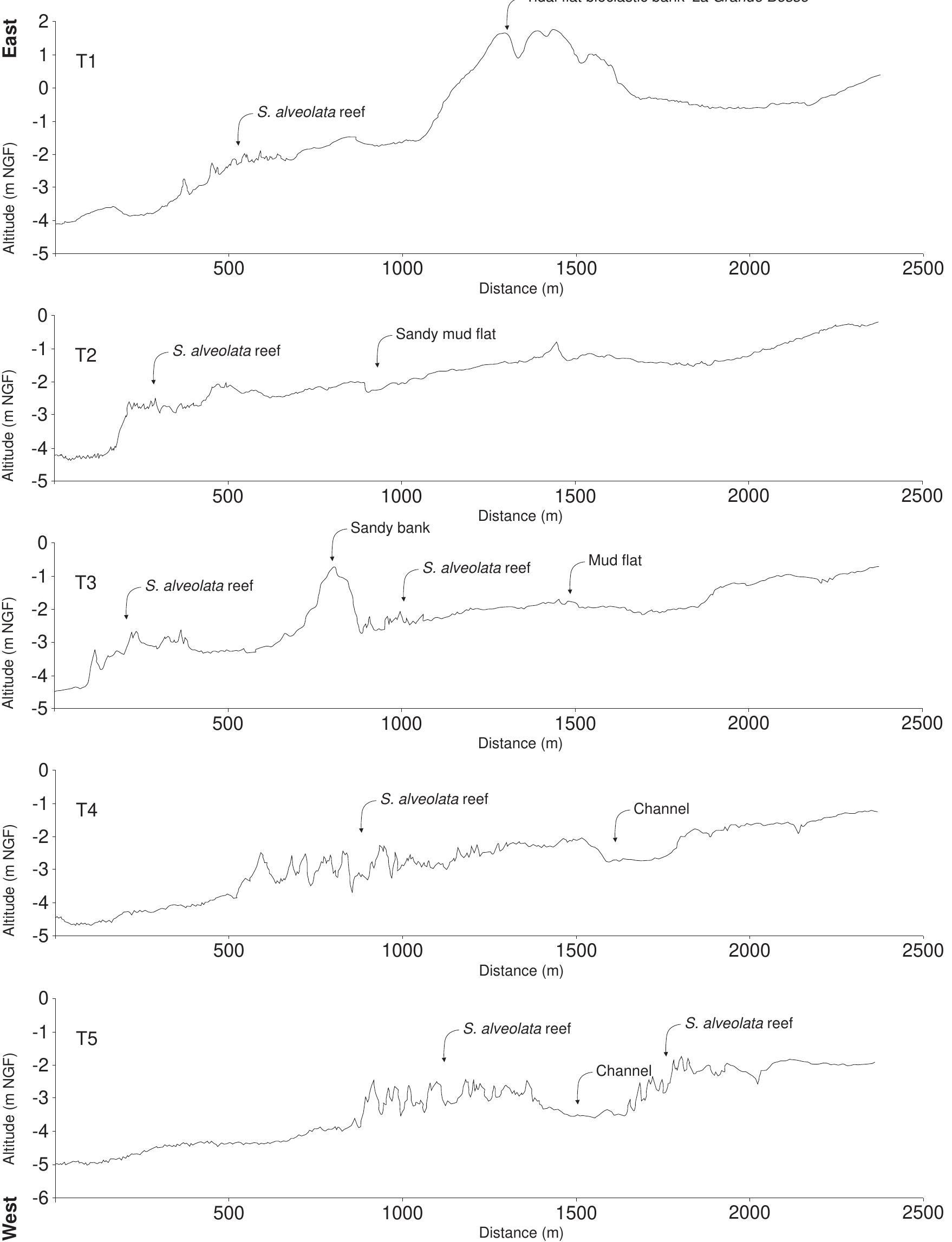